\section{Siyabonga: a humble hero making a difference with his hands... and his heart}

\author{
Jon Patricios
}

\section{ABSTRACT}

Siyabonga Kunene's athletic build and confident stance belie his humble roots. Born in an impoverished area of South Africa, he soon learnt the benefits of an education. He is now a PhD-qualified sports physiotherapist making a significant contribution in both academic and clinical realms. Remaining true to his origins and the inspirational words of Nelson Mandela, Siyabonga has created a framework for managing patellofemoral pain in under-resourced athletes. He has established himself as a physiotherapy lecturer at his university and has been appointed to national teams in his professional capacity. However, his focus primary remains on treating those with a passion for sport who would not normally be able to access high-level athletic care.

'Siyabonga' means 'We thank you' in isiZulu, the predominant African dialect in KwaZulu-Natal, the South African Province in which Dr Siyabonga Kunene was born. Siyabonga's tall, confident stance belies his modest beginnings. Born to poor, small-scale farmers in a rural village called Driefontein, his early days were spent herding cattle. His services were regarded as indispensable, to the extent that the start of his schooling was delayed.

\section{THE STUDENT ATHLETE}

Neither of his parents completed their schooling in Apartheid South Africa, where black people were subjected to an inferior education system. When he did start junior school, Siyabonga was appreciative of the opportunity an education might give him, and he applied himself diligently. While not at school, he still drove a tractor, ploughed fields and cared for his siblings. His daily journey was on bare feet, to a school whose infrastructure was poor and classrooms under-resourced. However, his dedicated teachers lit a flame

Correspondence to Professor Jon Patricios Wits Sport and Health (WiSH), School of Clinical Medicine, Faculty of Health Sciences, Wits University, Johannesburg-Braamfontein, Gauteng, South Africa; jpat@mweb.co.za that would see Siyabonga grasp the nettle and deal with societal inequities. He also became an accomplished track-and-field athlete, especially in long jump. His grades were good enough to earn him a bursary from the provincial health department to study a BSc (Physiotherapy) at the Medical University of South Africa (MEDUNSA). While studying, he worked after hours and sent money home. His career as a physiotherapist began in the public sector after which he registered for a master's degree in sports physiotherapy at MEDUNSA.

\section{A SPORTS PHYSIOTHERAPIST}

Having postgraduate qualifications in sports physiotherapy afforded Siyabonga the opportunity to work with a spectrum of athletes, including many at an elite level. He has been selected as team physiotherapist for the South African Paralympic Team for Tokyo 2021. However, he has never forgotten his roots, and it has troubled him that athletes in disadvantaged areas do not have access to adequate treatment and rehabilitation. His solution: study one of the most common running injuries, patellofemoral syndrome, in disadvantaged runners and develop a community-based rehabilitation programme and framework for implementation. This formed the basis for his PhD, completed at the University of KwaZuluNatal in 2020. (figure 1). His work includes several published papers revealing a high incidence $(40 \%)$ of anterior knee pain (AKP) and its significant impact on athletes from under-resourced communities where AKP affected running and energy levels and emotional well-being. ${ }^{12}$ The research is set in environments where clinical support is lacking and pragmatically describes the evaluation of athletes with knee pain and the application of an evidence-based rehabilitation programme overseen by coaches and managers. ${ }^{3}$ The framework proposes the establishment of a transdisciplinary rehabilitation team to screen injuries, plan, implement, monitor and evaluate rehabilitation programmes in under-resourced communities. Thereafter, via a task-shifting approach, knowledge is transferred to less skilled community members, while tertiary institutions provide ongoing remote support where further medical evaluation (eg, X-rays and gait analysis) or interventions (eg, orthoses) are needed. ${ }^{4}$

\section{THE PATELLOFEMORAL PROGRAMME (PFP)}

The stages of implementation of the PFP programme are:

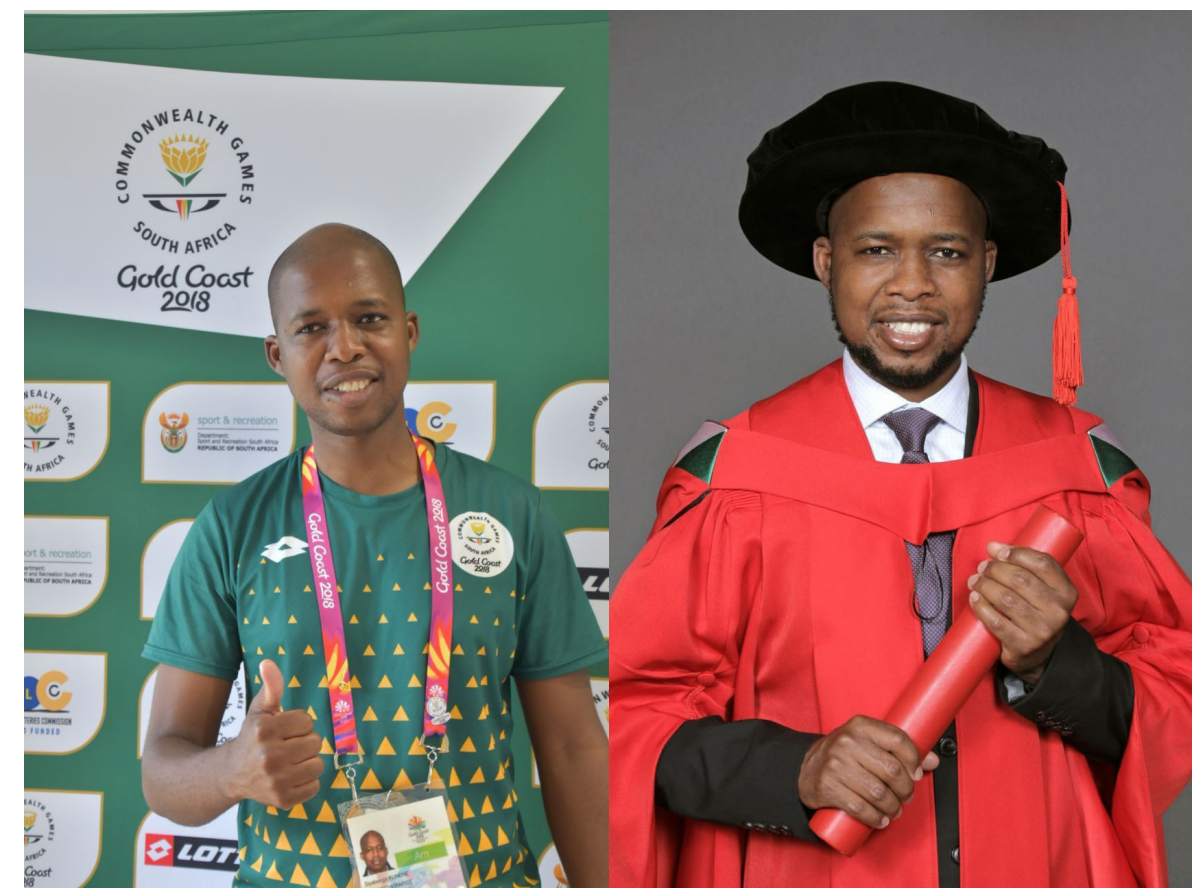

Figure 1 Siyabonga Kunene: sports physiotherapist and PhD graduate. 
1. High-level engagement: the screening of runners by physiotherapists and other members of a PFP sports rehabilitation committee, planning and customising of the programme.

2. Training of coaches and managers in PF rehabilitation. The comprehensive guidance includes education of runners, trainers and managers in PFP, immediate treatment, patella and soft tissue mobilisation, stretching exercises, proximal lower limb strengthening, core stabilisation, gait retraining, footwear/orthoses, warm-up and cooldown, progressive loading, varying surfaces, nutritional support and counseling to address mental, emotional and social well-being.

3. Implementation by coaches and managers.

4. Referral of complicated or recalcitrant cases back to the sports rehabilitation committee for further investigation and management.

Siyabonga is aware of the need to make the programme sustainable. To this end, he is engaging colleagues at Wits Sport and Health (WiSH) to assist in the education process as well as to provide tertiary support. The impact is likely to be significant and may allow many runners and other sports participants to continue gaining the benefits of exercise we are all so aware of. In communities where other forms of recreation are hard to come by, the effect could be even greater.

\section{AN ACADEMIC AND A CLINICIAN}

Siyabonga is now in the process of being promoted to senior lecturer in physiotherapy at Wits, where he oversees the student sports clinic, serves on the management committee of WiSH and strategises the implementation of his rehabilitation framework in underresourced communities.

\section{GRATITUDE}

Siyabonga's parents may have indeed had a premonition. They were certainly right to be thankful for their first-born child who, in a fledgling career, has shown his humanitarian side, directed sport and exercise medicine (SEM) research to an area of societal need and positively impacted sports medicine practice in under-resourced communities. Dr Kunene, the student, athlete, lecturer, researcher, clinician and humble human being, your colleagues and patients really do say, 'Thank you!'.

\section{Twitter Jon Patricios @jonpatricios}

Contributors JP is the sole contributing author. He conceived the idea of the piece, interviewed the clinician, researched his work and drafted the manuscript. Images were supplied by the clinician

Funding The authors have not declared a specific grant for this research from any funding agency in the public, commercial or not-for-profit sectors.
Competing interests None declared.

Patient consent for publication Not required.

Provenance and peer review Commissioned; internally peer reviewed.

Data availability statement No data are available. Not applicable.

(C) Author(s) (or their employer(s)) 2021. No commercial re-use. See rights and permissions. Published by BMJ.

$$
\text { (D) Check for updates }
$$

To cite Patricios J. Br J Sports Med 2021;55:566-567.

Accepted 10 March 2021

Published Online First 15 April 2021

Br J Sports Med 2021;55:566-567.

doi:10.1136/bjsports-2021-104118

\section{ORCID iD}

Jon Patricios http://orcid.org/0000-0002-6829-4098

\section{REFERENCES}

1 Kunene S, Ramklass S, Taukobong N. Anterior knee pain and its extrinsic risk factors among runners in underresourced communities in Ekurhuleni, Gauteng, South Africa. S Afr J Sports Med 2019:31:1-6.

2 Kunene SH, Ramklaas S, Taukobong NP. The impact of anterior pain on the quality of life among runners in under-resourced communities in Ekurhuleni, Gauteng, South Africa. S Afr J Sports Med 2018:30:1-6.

3 Kunene SH, Taukobong NP, Ramklass S. Rehabilitation approaches to anterior knee pain among runners: a scoping review. South African Journal of Physiotherapy 2020;76:a1342.

4 Kunene SH, Taukobong NP, Ramklass S. CommunityBased rehabilitation implementation framework to address patellofemoral pain among runners in underresourced communities: Delphi consensus. South African Journal of Physiotherapy. Under review. 